Article

\title{
Environmental Assessment of Integrated Food and Cooking Fuel Production for a Village in Ghana
}

\author{
Andreas Kamp ${ }^{1}$, Hanne Østergård ${ }^{1, *}$ and Simon Bolwig ${ }^{2}$ \\ 1 Department of Chemical and Biochemical Engineering, Technical University of Denmark, DTU, \\ 2800 Kongens Lyngby, Denmark; ankam@kt.dtu.dk \\ 2 Department of Management Engineering, Technical University of Denmark, DTU, \\ 2800 Kongens Lyngby, Denmark; sibo@dtu.dk \\ * Correspondence: haqs@kt.dtu.dk; Tel.: +45-21-32-69-55
}

Academic Editor: Andrew Kusiak

Received: 4 March 2016; Accepted: 14 April 2016; Published: 26 April 2016

\begin{abstract}
Small-scale farming in Ghana is typically associated with synthetic fertilizer dependence and soil degradation. The farmers often rely on wood fuel for cooking imported from outside the farmland, a practice that is associated with deforestation. Integration of food and energy production may be a holistic approach to solving these issues. We study four approaches to providing food and fuel for cooking in a small-scale farming community. Present practice (PP) of synthetic fertilizer based food production and provision of wood fuel from outside the farming area is compared to three modeled, integrated technology options: integrated food and household-scale biogas production (HH Biogas), integrated food and village-scale biogas production (Village Biogas), and integrated food and wood fuel production (Agroforestry). Integrated approaches are able to eliminate the import of wood fuel, reduce synthetic fertilizer use by $24 \%, 35 \%$ and $44 \%$ and soil loss by $15 \%, 20 \%$ and $87 \%$, respectively, compared to present practice. An Emergy Assessment (EmA) shows that integrated approaches are relevant substitutes to present practice considering biophysical efficiency indicated by Unit Emergy Value (in solar emjoules (sej) per J of output) and dependence on renewable inputs indicated by the Global Renewability Fraction (in \%): $2.6-3.0 \times 10^{5} \mathrm{sej} / \mathrm{J}$ and $38 \%-48 \%$ (PP), $2.5-2.8 \times 10^{5} \mathrm{sej} / \mathrm{J}$ and $41 \%-46 \%$ (HH Biogas), $2.4-2.6 \times 10^{5} \mathrm{sej} / \mathrm{J}$ and $45 \%-47 \%$ (Village Biogas), $1.7-2.4 \times 10^{5} \mathrm{sej} / \mathrm{J}$ and $49 \%-66 \%$ (Agroforestry). Systematic recycling and use of local resources may play a pivotal role in reducing the dependence on non-renewable resources in Ghanaian farming, ensuring long-term soil fertility and stemming the current deforestation of wood reserves.
\end{abstract}

Keywords: biogas; agroforestry; nutrient recycling; transition; sustainable development; emergy; Ghana; case study

\section{Introduction}

A key argument in the debate on sustainable development is that societies must transition away from the high use of fossil fuels and other non-renewable resources because of increased scarcity and/or due to their harmful effects on the environment including the climate [1-3]. For agriculture, such a transition involves finding alternatives to a range of common farm inputs without further depleting soil and forest resources. In developing countries, low-tech solutions are often suggested as they are deemed more suitable to economic and institutional conditions than advanced technologies. In this paper, we study farming and wood fuel provision in rural area Ghana and assess three low-tech alternatives to present practices with respect to reducing soil loss, deforestation and the use of synthetic fertilizers.

The high rates of resource extraction as well as the climate effects of fossil fuels call into question the sustainability of dominant food production technologies. These technologies depend strongly 
on the use of fossil fuels, especially for the production of synthetic fertilizers and running of farm machinery, and of other non-renewable resources such as phosphorus [4-7]. Østergård et al. thus suggest that a paradigm shift in modern agriculture is necessary to deal with major environmental problems, especially soil deterioration, biodiversity loss, resource depletion, and pollution [8].

Yet reducing the use of fossil fuels and other non-renewable resources is often difficult due to limited local availability of biological resources above and below the ground, particularly forests and soil organic matter. In Ghana, the current rate of deforestation is around $2 \%$ per year $[9,10]$ and the use of wood fuel for heating and cooking has been identified as a main driver [11,12]. Prevalent farming practices deteriorate soil quality through the loss of soil carbon from erosion and tilling [13] and through the removal of plant nutrients due to leaching and in the harvested product [14]. Together these processes undermine agricultural productivity and the livelihood of farmers $[15,16]$. In light of the above, a key premise of this paper is that sustainable agricultural development in Ghana and other developing countries must simultaneously address issues of increasing non-renewable resource scarcity and their polluting effects as well as deforestation and soil degradation.

The knowledge base for adapting farming systems to the resource and pollution challenges just outlined is already largely available. It includes the incorporation of organic matter into soils, reducing soil tillage, appropriate crop and husbandry management, and more general "low tech" or "soft technology" approaches [8]. Biogas and agroforestry are part of this knowledge base. The benefits and applicability of biogas in developing countries are well documented (e.g., [17-19]). Benefits include reduced dependence on imported energy and fertilizer, improved health, workload reduction, and the proximity of feedstock and biogas users. High-solids, non-manure-based digestion is particularly relevant in many developing countries, since water and manure are often not easily available [20]. Agroforestry practices have been shown to improve crop yields, reduce erosion, provide fodder and protect crops on millions of hectares in Africa [21]. It has been shown that certain tree species in agroforestry systems provide significant amounts of $\mathrm{N}$ through nitrogen fixation, constituting a profitable alternative to conventional fertilization methods [22].

Biogas and agroforestry meet several of the criteria for technologies that are central for a successful transition of agriculture. Few studies, however, have emphasized the specific ability of these technologies to address simultaneously the issues of organic substitutes for synthetic fertilizers, deforestation, and soil degradation. To fill this gap, we studied the provision of food and cooking fuel in a village in rural area Ghana through a comparison of four technology options (also referred to as "approaches"): present practice, household-scale biogas, village-scale biogas, and agroforestry, where the latter three approaches integrate food and energy production in different ways. We used case study data on small-scale farming and wood fuel production collected in Ghana and data from the literature on biogas and agroforestry production. Two of the four technology options consider high solids digestion of crop residues, a technique that has received little scholarly attention compared to low solids, manure-based digestion. Biogas production scale may be an important parameter [23], and we investigate whether there is difference between household-scale and village-scale production.

Our assessment applies a systems perspective by considering the production of food and energy as one integrated system. This follows the concept of integrated food and energy systems that combine food and energy production on a local level with the objective of achieving synergy effects in the larger, integrated system [24].

We compare and analyze technology profiles in terms of mass balance and labor requirements. Using emergy methodology [25], we assess the environmental performance of the four technology options with respect to resource use efficiency in a biophysical perspective and the degree to which each approach depends on renewable resources. Emergy assessment systematically includes labor inputs along with material and energy inputs, allowing for detailed labor analyses. We elaborate on the role of labor and account for labor embodied in imported inputs in a novel way.

Our results are used to evaluate whether the three integrated food and energy systems are relevant alternatives to present food and energy provision practices since these may no longer be relevant 
during a transition of society. Our hypothesis is that the studied, integrated technology options are as biophysically efficient and as independent from non-renewable resources as present practice. The evaluation permits a ranking of approaches that can be used to prioritize implementation.

\section{Materials and Methods}

\subsection{Present Practice Case Study}

The study area, the village of Zambrama and its farmlands, is located in the transitional zone of the semi-deciduous forest and Guinea Savannah zones near Ejura town, Ghana. The climate is tropical with average annual rainfall of $1200 \mathrm{~mm}$ and solar irradiation of $5.2 \mathrm{kWh} / \mathrm{m}^{2} /$ day. Data on material, energy and labor inputs in farming and the resulting outputs was collected by interviewing farmers before and after key farming activities during three growing seasons in the period 2012-2013. Farmers were selected based on interest in collaboration and adjacency of fields. Data on wood fuel usage and charcoal production in Zambrama was collected in 2013. The studied farm area comprises 45 hectares (ha), approximately a fourth of the village's farmed hinterland. Seven households farm this area.

The dominant farming system in the study area is a rotational bush fallow system characterized by a dominance of maize ( $89 \%$ of the area), followed by cowpea $(4 \%)$, and a few other subsistence and cash crops (7\%). No significant livestock were held. Farming is characterized by a high degree of manual labor and the external inputs of synthetic fertilizer, pesticides, machinery, and diesel (for ploughing, de-husking and local transport of produce).

The current technology option for obtaining food and cooking energy, Present Practice (PP), is small-scale, semi-mechanized, pesticide and synthetic fertilizer-based food production with imported wood fuel (Figure 1). The wood fuel is used entirely for cooking using a three-stone stove for firewood with a thermal energy yield of $8 \%$ or a coal pot stove for charcoal with a thermal energy yield of $22 \%$ [26].

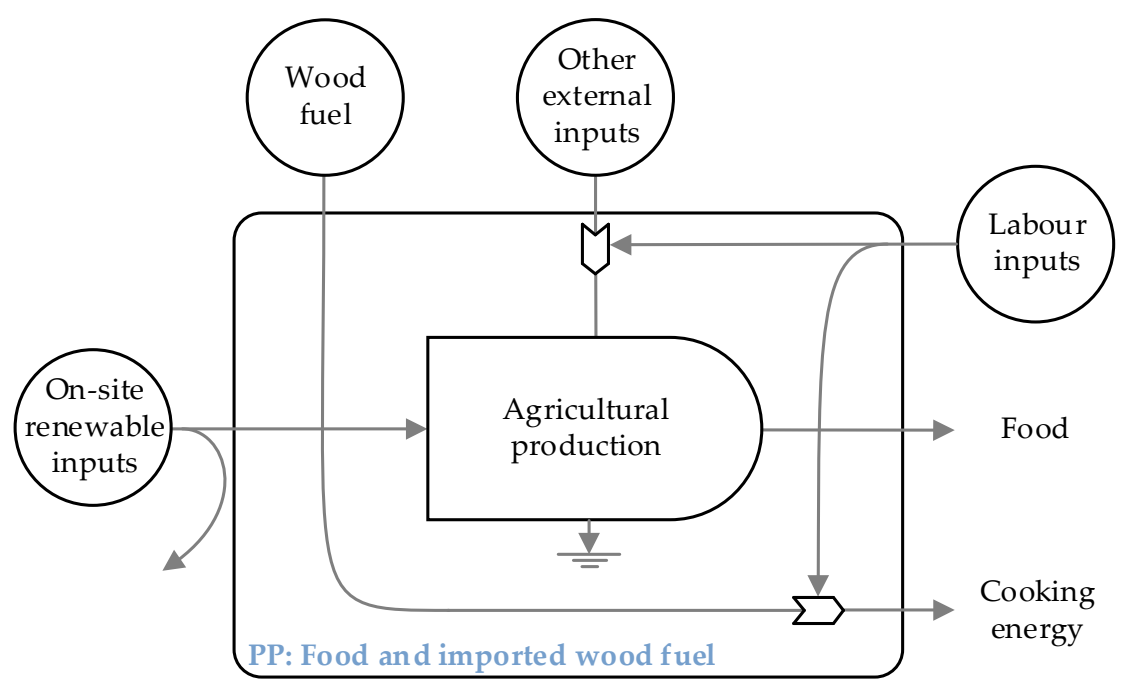

Figure 1. Schematic overview of present practice food and cooking energy provision.

\subsection{Integrated Food and Energy Systems}

The suggested substitutes for providing the same output as present practice are combinations of food and cooking energy provision technologies with the following characteristics and modeling assumptions:

For the PP, HH Biogas, and Village Biogas options soil organic carbon loss is set to $395 \mathrm{~kg} / \mathrm{ha} /$ year (before recycling), based on $[27,28]$. Biogas production is modeled with residue-to-product ratios from [29], and biogas potentials from [29,30]. For HH Biogas and Village Biogas, respectively, 
pre-digestion storage losses are $21 \%$ and $10 \%$ [31] while post-digestion, pre-application losses are set to $50 \%$ and $25 \%$ [32]. These assumptions result in required residue recovery fractions of $44 \%$ ( $\mathrm{HH}$ Biogas) and 36\% (Village Biogas), to match the outputs of PP. The biogas is used in a biogas cook stove with a thermal energy yield of 55\% [33]. For all technology options, the unrecovered crop residues are burned. This is a common practice to avoid wildfires and reduce pest pressure.

The household-scale biogas technology option (HH Biogas) is characterized by farming methods similar to PP but supplemented with recycled nutrients and carbon in the effluent from biogas production (Figure 2). Cooking fuel is assumed provided by seven household biogas plants, following an experimental high-solid anaerobic digestion design with plastic tanks [34]. Conversion efficiency is $43 \%$ of biomethane potential to match the cooking energy output of PP. This is within the range possible for this kind of anaerobic digestion [34,35].

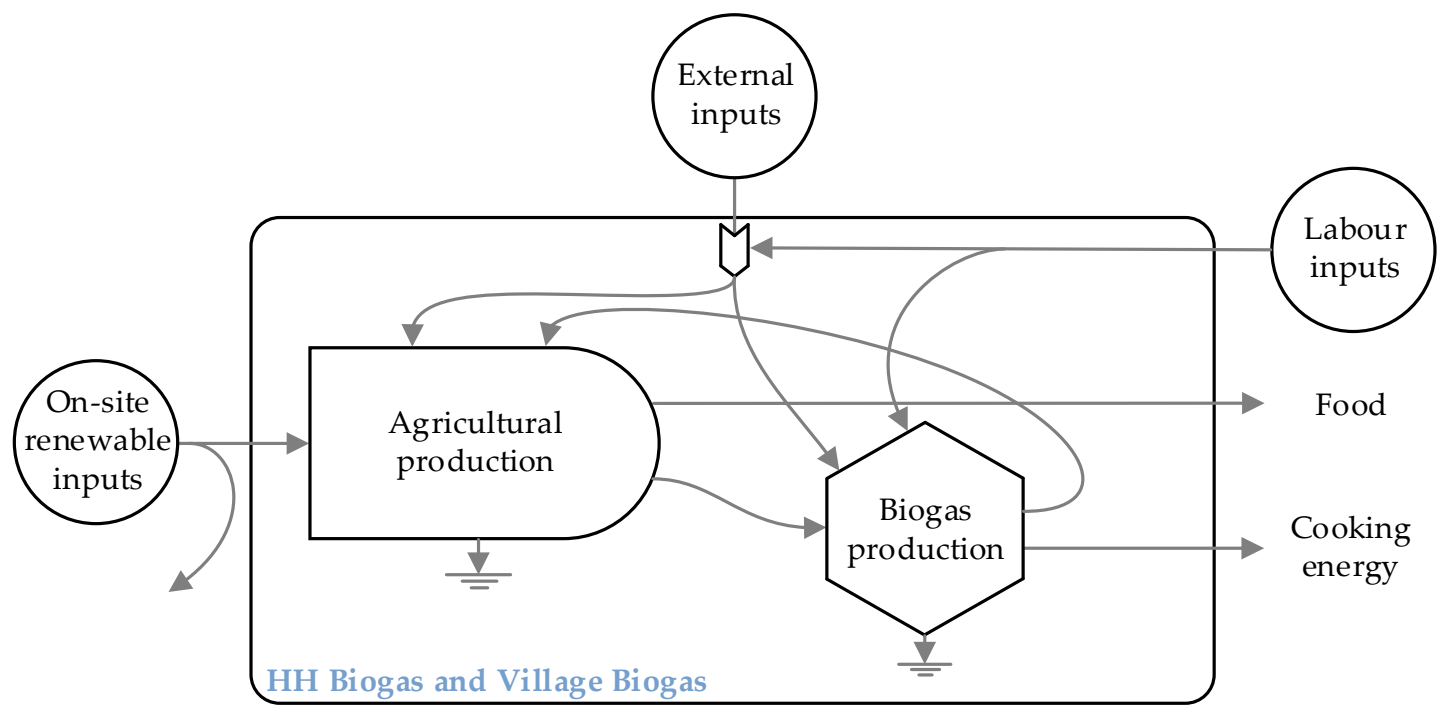

Figure 2. Schematic overview of integrated food and cooking energy production with biogas.

The village-scale biogas technology option (Village Biogas) is the same as the HH Biogas option but with a larger scale biogas production using a high-solids anaerobic digestion design in a shipping container (Figure 2). This design was tested at pilot scale at Kwame Nkrumah University of Science and Technology in Kumasi, Ghana [36]. The setup in [36] is experimental and supplies no specific conversion efficiency. We assume $50 \%$ conversion efficiency based on the range provided for another high-solids anaerobic digestion design [35] and the expectation that a larger scale is associated with a slightly higher conversion efficiency [34].

The agroforestry technology option (Agroforestry) is characterized by highly integrated wood and food crop production [21,37] (Figure 3). Maize and beans are grown in four-meter wide alleys between rows of leucaena trees (Leucaena Leucocephala, see [38] as demonstrated by [39]). Nutrient uptake from air and soil combined with mulching of pruning materials and littered leaves reduce synthetic fertilizer requirement by $50 \%$ (based on [38]) and soil organic matter loss by $87 \%$ [40]. Leucaena yields $5 \mathrm{t} / \mathrm{ha}$ /year firewood on the relevant part of the sample area (i.e., 40 ha) [41]. Labor requirements for leucaena cultivation, pruning and mulching are 50 man-hours/ha/year on 40 ha (based on [42]); these inputs are considered in addition to PP farming labor inputs. A part of the harvested/collected wood is used for firewood in a three-stone stove and a part is turned into charcoal and used in a coal-pot stove. The time used to collect wood fuel is assumed half of that in PP due to reduced distance to the wood resources. 


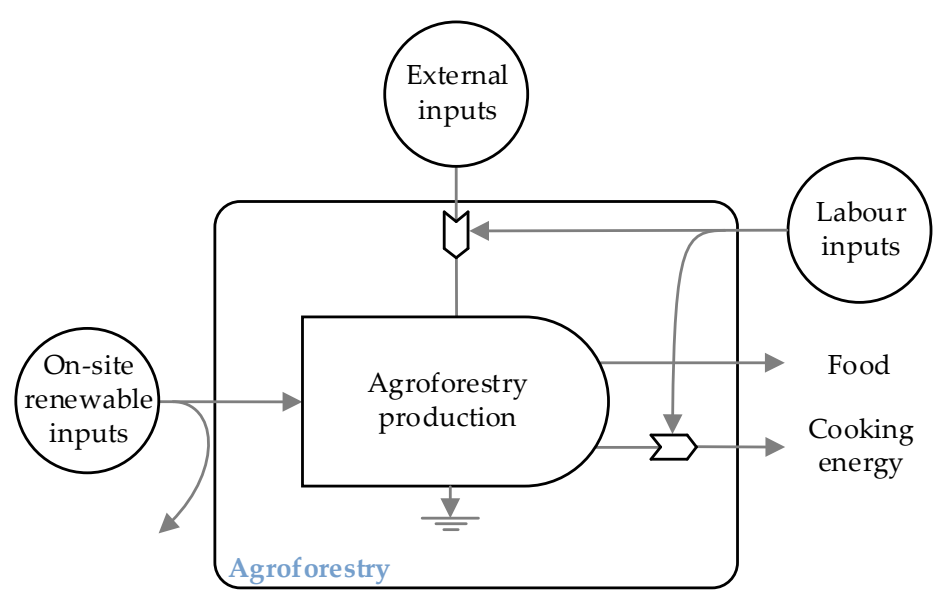

Figure 3. Schematic overview of integrated food and cooking energy production with agroforestry.

\subsection{Emergy Assessment (EmA)}

The Environmental Sustainability Assessment is carried out using EmA. EmA applies embodied energy analysis founded in thermodynamics. Emergy is defined as the solar energy required directly and indirectly to make a product or service [25]. All ms of energy, materials and human labor that contribute-directly or indirectly - to a production process are taken into account and converted into the common unit of solar emjoules (sej) [43]. The conversion takes place by multiplying physical quantities with their respective Unit Emergy Values (UEV), where the UEV is the emergy per unit (e.g., sej/J, sej/g, sej/man-hour). A high UEV is indicative of large, accumulated energy losses in the creation, extraction, transport, manufacture, etc. of a given item. The emergy value is considered an estimate of accumulated resource use. It follows that resource efficient processes result in low UEVs, and, therefore, it is a common objective in emergy assessments to compare processes that yield similar outputs and to conclude on resource efficiency.

\subsubsection{UEV Calculation}

The assessment of resource use in this study is based on an emergy baseline of $15.83 \times 10^{24} \mathrm{sej} /$ year [44]. The UEVs of the outputs are calculated as joint UEVs [45] applying a "full system" perspective [46]. The output is a "basket" of different food products and cooking energy, constituting in this context the most significant co-production outputs of the systems. The resulting resource use efficiency indicator, the UEV, is the solar emjoules required to provide one joule of output of basket mix. The food and useful cooking energy output for all options is defined by PP production. In $\mathrm{HH}$ Biogas, the conversion efficiency is set to match the cooking energy output of PP. In Village Biogas, where the conversion efficiency is assumed higher and storage losses smaller than in HH Biogas, a comparable output is ensured by recovering less crop residues. In Agroforestry, the positive and negative effects of co-production on crop yield have been considered and are assumed to balance out, based on the mentioned research (see Section 2.2). Matching cooking energy output in Agroforestry to that of PP is possible since there is much more wood available (approximately $200 \mathrm{t}$ ) than necessary (approximately $55 \mathrm{t}$ ). Unrecovered residues and wood are not accounted for as output. This is a conservative assumption regarding unused wood in Agroforestry.

\subsubsection{Renewability Fraction}

EmA allows for the categorization of resource use according to renewability, making it possible to quantify how renewable an output is [47]. All inputs that are required to make the studied system function are divided into three input categories: on-site renewable resources $(R)$, on-site non-renewable resources $(\mathrm{N})$ and feedbacks from society $(\mathrm{F})$ - i.e., external inputs. The Renewability Fraction (i.e., $\mathrm{R} /(\mathrm{R}+\mathrm{N}+\mathrm{F}))$ indicates the dependence on resources that are considered to be on-site and renewable [25]. 
When the renewability fraction of external inputs $\left(F_{R}\right)$ is included, the resulting renewability fraction of the output is not the fraction of on-site, renewable flows but the fraction of global, renewable flows $\left(\left(\mathrm{R}+\mathrm{F}_{\mathrm{R}}\right) /(\mathrm{R}+\mathrm{N}+\mathrm{F})\right)[48]$. In the following, we refer to the Global Renewability Fraction to distinguish from the Renewability Fraction based on on-site, renewable inputs. The higher Global Renewability Fraction, the less dependent on non-renewable inputs the system is.

\subsubsection{Labor Accounting}

EmA routinely accounts for what can be referred to as "the biophysical cost of human labor". The accounting of labor inputs follows the guidelines presented in [49] and distinguishes between direct labor and indirect labor. Direct labor takes place in the "foreground" of the assessment and comprises the man-hours required for farming and cooking fuel collection or production. The resource use supporting direct labor is differentiated across different labor types, using a UEV of $3.2 \times 10^{12} \mathrm{sej} / \mathrm{man}$-hour for farm work and $9.1 \times 10^{12} \mathrm{sej} / \mathrm{man}$-hour for specialist labor (chainsaw operation and village biogas plant management) [49].

Indirect labor takes place in the "background", i.e., in production systems that supply inputs to farming and cooking energy production (e.g., diesel production), and this labor accompanies purchased goods and services in the form of an estimate of man-hours required. If detailed knowledge of specific labor inputs in background systems is missing, an estimate may be approximated through the monetary cost of individual inputs. Monetary cost is converted to global man-hours using an average global conversion rate, assuming that each USD of indirect labor is equally dependent on all activities of the global economy. This rate is based on an estimate of the labored hours in a year $\left(5.7 \times 10^{12}\right.$ man-hours/year, own calculation) divided by the Gross World Product $\left(6.1 \times 10^{13} \mathrm{USD} /\right.$ year [50]) to give an average, global man-hour/USD (0.09 man-hours/USD). The UEV for indirect labor, $1.8 \times 10^{13} \mathrm{sej} /$ global man-hour, is calculated as global emergy flow $\left(1.1 \times 10^{26} \mathrm{sej} /\right.$ year [50] $)$ divided with global labor force $\left(3.1 \times 10^{9}\right.$ persons [51] and average work year (1840 hours / person/year, own estimate).

\subsubsection{UEVs of Firewood and Charcoal}

As part of the calculations for PP, the UEVs of firewood and charcoal are calculated. For charcoal, the estimate is based on an interview with a charcoal producer and a chainsaw operator. The UEVs are estimated to $3.06 \times 10^{11} \mathrm{sej} / \mathrm{kg}$ and $2.09 \times 10^{12} \mathrm{sej} / \mathrm{kg}$, for firewood and charcoal, respectively, excluding labor, and $3.70 \times 10^{11} \mathrm{sej} / \mathrm{kg}$ and $2.17 \times 10^{12} \mathrm{sej} / \mathrm{kg}$, respectively, including labor. These calculations are shown in the Supplementary Materials.

\subsection{Sensitivity Analysis}

We evaluate the sensitivity of emergy indicator results to changes in five selected, independent parameters. Two sets of extreme parameter values were defined and designated "More inputs, non-renewable imported wood" and "Less inputs, renewable imported wood" (Table 1).

Table 1. Uncertainty ranges for parameter values evaluated in the sensitivity analysis.

\begin{tabular}{ccccc}
\hline $\begin{array}{c}\text { Technology } \\
\text { Option a }\end{array}$ & Parameter & $\begin{array}{c}\text { More Inputs, } \\
\text { Non-Renewable } \\
\text { Imported Wood }\end{array}$ & $\begin{array}{c}\text { Reference Model } \\
\text { Parameter Values }\end{array}$ & $\begin{array}{c}\text { Less Inputs, } \\
\text { Renewable } \\
\text { Imported Wood }\end{array}$ \\
\hline All & Labour inputs & $30 \%$ more & Present practice & $30 \%$ less \\
All & Global Ren. Fraction of wood & $0 \%$ & $50 \%$ & $100 \%$ \\
HH Biogas & Conversion efficiency & $30 \%$ & $43 \%$ & $52 \%$ \\
Village Biogas & Conversion efficiency & $35 \%$ & $50 \%$ & $55 \%$ \\
Agroforestry & Soil loss reduction & $61 \%$ & $87 \%$ & $100 \%$ \\
\hline
\end{tabular}

a Technology options are described in Sections 2.1 and 2.2. 
Results from the sensitivity analysis are presented as ranges of UEV and Global Renewability Fraction for each technology option, respectively.

\section{Results}

The assessment of technology options leads to profiles that include outputs, ability to cycle nutrients and reduce soil loss and labor requirements. The emergy indicators for resource use efficiency and renewability are presented with and without labor inputs. Full emergy tables and calculation notes are available in the Supplementary Materials.

\subsection{Mass Balance and Labor Inputs}

\subsubsection{Present Practice}

Production outputs of 55 tons (dry matter) of food and 79 GJ of end-use thermal energy are obtained using approximately $3200 \mathrm{~kg}$ of synthetic fertilizer, 18 tons of soil organic carbon in lost soil, 67 tons of wood, 18,000 man-hours in the fields and to transport and convert fuels, and 510 global man-hours embodied in purchased inputs (Table 2). Labor inputs are specified in the Supplementary Materials.

Table 2. Technology profiles. Values are for an agricultural system of 45 hectares in one year, unless otherwise stated.

\begin{tabular}{cccccc}
\hline & & \multicolumn{4}{c}{ Technology Option a } \\
\cline { 3 - 5 } & Unit & PP & $\begin{array}{c}\text { HH } \\
\text { Biogas }\end{array}$ & $\begin{array}{c}\text { Village } \\
\text { Biogas }\end{array}$ & Agroforestry \\
\hline Input & & & & & \\
\hline Imported cooking fuel & tons & 67 & 0 & 0 & 0 \\
Synthetic fertilizer use & kg & 3200 & 2400 & 2100 & 1800 \\
Soil loss & tons soil organic carbon & 18 & 14 & 13 & 2.3 \\
Direct labor & man-hours & 18,000 & 23,000 & 22,000 & 20,000 \\
Indirect labor & global man-hours & 510 & 510 & 480 & 410 \\
\hline Output & & & & & 55 \\
\hline Food & tdm & 55 & 55 & 55 & 79 \\
\hline Useful cooking energy & GJ thermal energy & 79 & 79 & 79 & \\
\hline
\end{tabular}

\subsubsection{Integrated Food and Energy Systems}

Production outputs of the three integrated systems are equal to PP (Table 2). All integrated approaches fully substitute for imported wood fuel. The following results are relative to PP:

The nutrient cycling supported by residue recovery, anaerobic digestion and subsequent effluent return to fields is able to substitute $24 \%$ of synthetic fertilizer in the case of $\mathrm{HH}$ Biogas and $35 \%$ in the case of Village Biogas, while mulching of leucaena leaf litter is able to reduce synthetic fertilizer inputs by $44 \%$ with Agroforestry. The carbon management practices can reduce the net loss of soil carbon by $22 \%$ and $29 \%$ for the two biogas-based systems, respectively, and $87 \%$ with Agroforestry.

Direct labor requirements are larger in the integrated approaches $(\mathrm{HH}$ Biogas: $+31 \%$, Village Biogas: $+24 \%$ and Agroforestry: $+10 \%$ ) indicating that a reduced dependence on material inputs comes at the cost of higher labor inputs.

Indirect labor requirements are similar or lower in the integrated approaches (HH Biogas: 510 global man-hours/year, Village Biogas: $-5 \%$ and Agroforestry $-20 \%$ ). This suggests that integrated food and cooking energy production relies less on labor embodied in purchased inputs. Indirect labor represents merely $2 \%-3 \%$ of labor inputs. 


\subsection{Emergy Analysis}

\subsubsection{Present Practice}

When accounting for inputs in emergy, the resource use is $280,000 \mathrm{sej} / \mathrm{J}$ of output with approximately $51 \%$ of renewable origin (Table 3). The relative importance of inputs are shown as percentages of the total input (Figure 4). The most dominant inputs are rain (35\%), soil (28\%), direct labor $(18 \%)$, and wood fuel (7\%). Among the inter-dependent flows of sun, wind and rain, rain is the most prominent at this location and thus the only one included in the calculations.

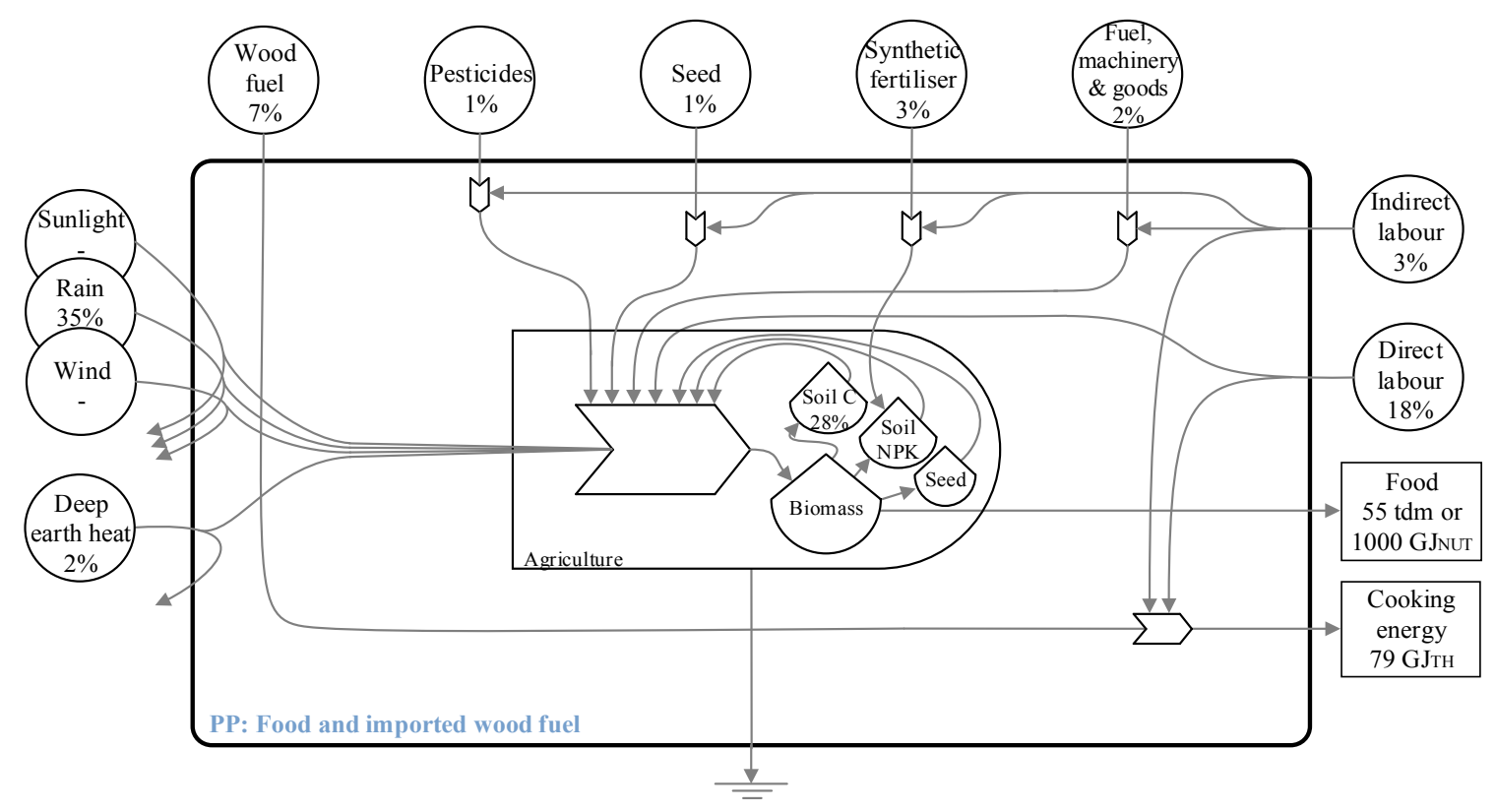

Figure 4. Separate food and cooking fuel production. Inputs are in percentage of the total emergy flow $3.1 \times 10^{17} \mathrm{sej} /$ year on 45 ha.

When excluding labor inputs, the resource use per unit of output is considerably lower and the Global Renewability Fraction higher (Table 3). This is because labor inputs constitute $21 \%$ of total inputs and because the Global Renewability Fractions of labor are low (see Supplementary Materials). Soil loss, synthetic fertilizer and diesel inputs are the remaining significant sources of non-renewable inputs (not shown).

Table 3. Technology profiles with emergy indicators.

\begin{tabular}{cccccc}
\hline & & \multicolumn{3}{c}{ Technology Option a } \\
\cline { 3 - 6 } & Unit & PP & HH Biogas & Village Biogas & Agro-forestry \\
\hline Unit Emergy Value, incl. labor & $10^{5} \mathrm{sej} / \mathrm{J}$ & 2.8 & 2.7 & 2.6 & 2.0 \\
Unit Emergy Value, excl. labor & $10^{5} \mathrm{sej} / \mathrm{J}$ & 2.2 & 1.9 & 1.8 & 1.3 \\
Global Ren. Fraction, incl. labor & $\%$ & 43 & 43 & 45 & 58 \\
Global Ren. Fraction, excl. labor & $\%$ & 51 & 56 & 58 & 80 \\
\hline
\end{tabular}

a Technology options are described in Sections 2.1 and 2.2.

\subsubsection{Integrated Food and Energy Systems}

The Emergy Assessment of biophysical resource efficiency ranks Agroforestry as 31\% more efficient than PP. HH Biogas and Village Biogas are 6\% and 9\% more efficient than PP, respectively (Table 3). The relative importance of inputs are shown as percentages of the total input in Figures 5-7. 
In all three integrated approaches, labor plays a larger role, and for Agroforestry, soil loss is significantly reduced, compared to PP.

The Global Renewability Fractions of HH biogas and Village biogas are similar to PP. The Agroforestry approach is considerably better at reducing dependence on non-renewable inputs. This is primarily because Agroforestry significantly reduces soil loss and leaching and fixates nitrogen from the air.

Excluding labor from the calculation provides a consistent picture of improved efficiency and renewability of integrated approaches compared to PP.

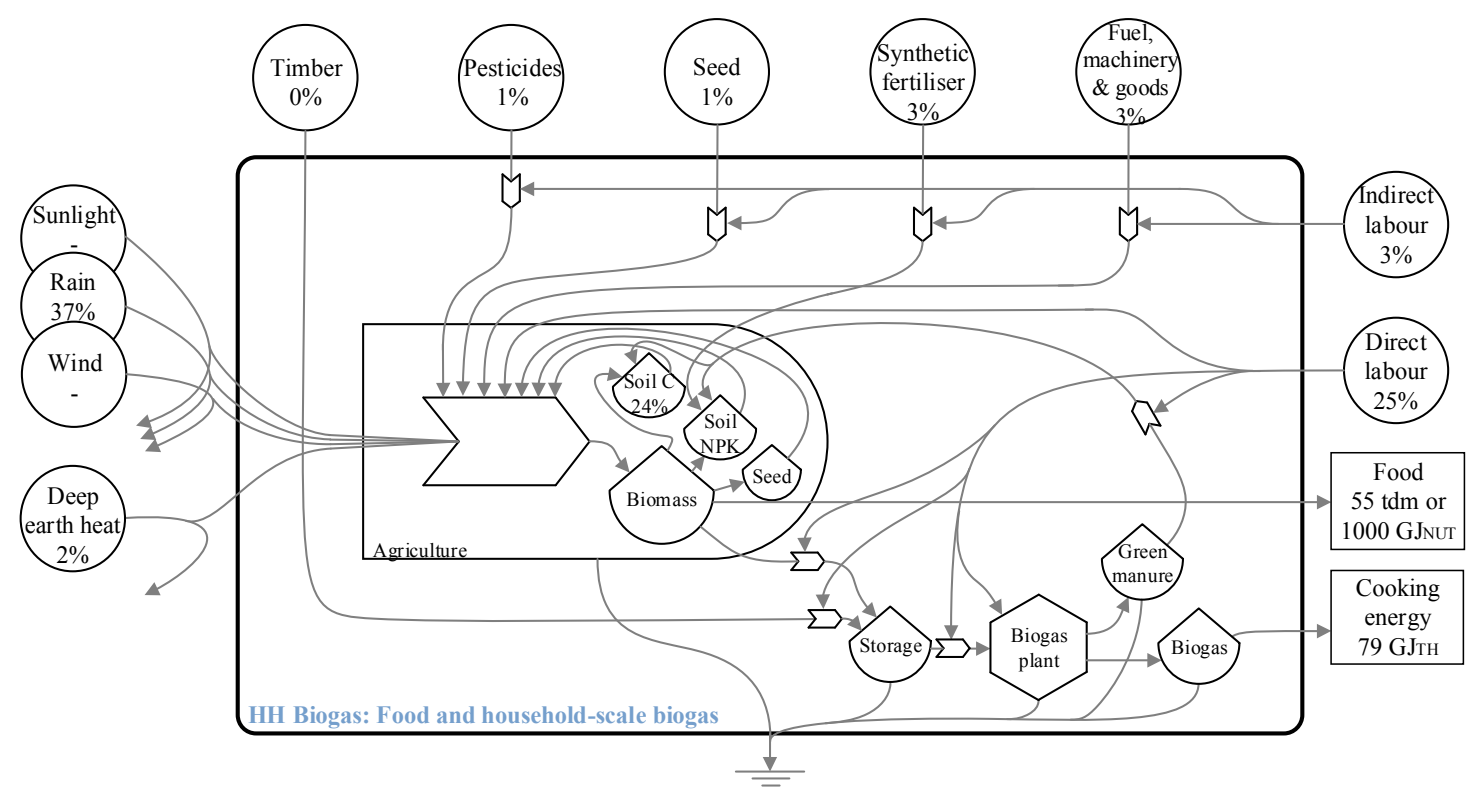

Figure 5. Integrated food and cooking fuel production based on household-scale biogas production with recycling of nutrients and carbon. Inputs are in percentage of the total emergy flow $2.9 \times 10^{17} \mathrm{sej} /$ year on 45 ha.

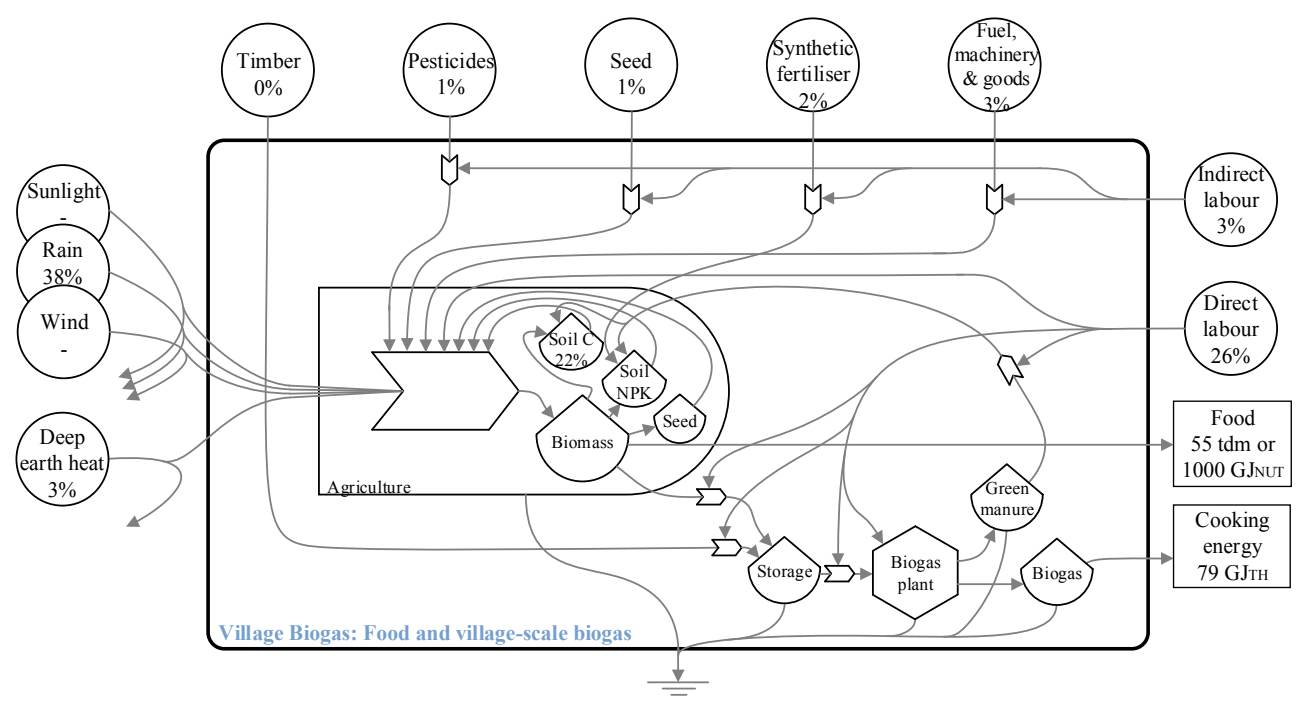

Figure 6. Integrated food and cooking fuel production based on village-scale biogas production with recycling of nutrients and carbon. Inputs are in percentage of the total emergy flow $2.8 \times 10^{17} \mathrm{sej} /$ year on 45 ha. 


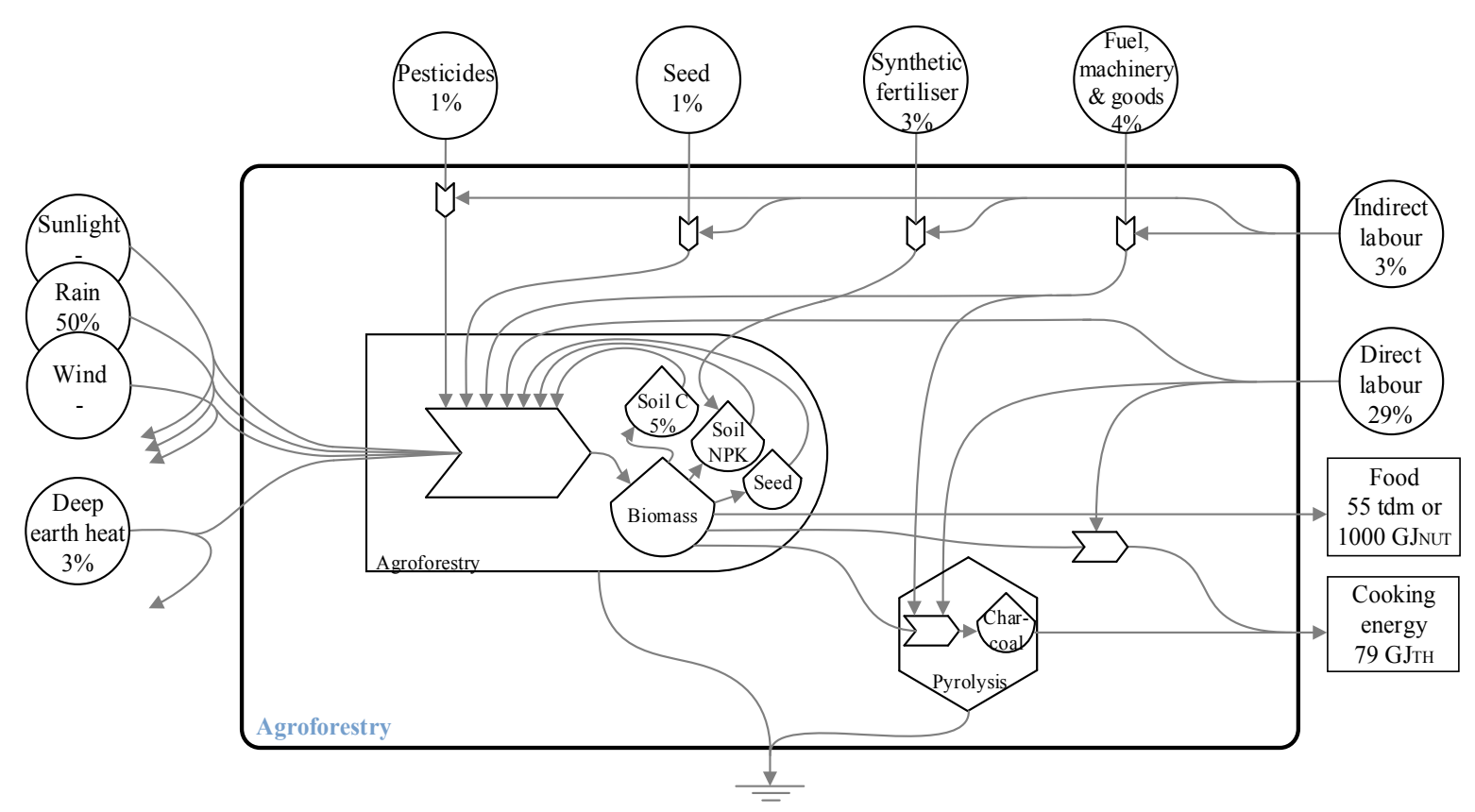

Figure 7. Integrated food and cooking fuel production based on alley cropping with maize and leucaena. Inputs are in percentage of the total emergy flow $2.2 \times 10^{17} \mathrm{sej} /$ year on 45 ha.

\subsection{Sensitivity Analysis}

The sensitivity analysis is based on changes in five parameters values, which we expect to be especially uncertain (see Section 2.4). At first, we suggest a substantial margin for labor input estimates in farming, biogas production management and agroforestry. We also consider the conversion efficiency in biogas production to be subject to significant variation since the biogas digester designs are not thoroughly tested. The ability of agroforestry practices to reduce soil loss is dependent on a range of variables that may or may not apply under the specific conditions. Finally, the renewability fraction of wood used for wood fuel depends on how to define renewability of a resource that is based primarily on renewable flows and at the same time is subject to a use that exceeds the regeneration rate. This debate is beyond our scope, and we choose to apply three different Global Renewability Fractions for wood fuel.

Altering the values of the selected parameters results in ranges for each of the calculated indicators (Table 4). Ranges are slightly larger for biogas and agroforestry since the uncertainty of biogas conversion efficiency and soil loss reduction in agroforestry apply to these technologies.

Table 4. Ranges of indicator values resulting from the sensitivity analysis.

\begin{tabular}{cccccc}
\hline & & \multicolumn{4}{c}{ Technology Option a } \\
\cline { 3 - 6 } & Unit & PP & HH Biogas & Village Biogas & Agro-forestry \\
\hline Unit Emergy Value, incl. labor & $10^{5} \mathrm{sej} / \mathrm{J}$ & $2.6-3.0$ & $2.5-2.8$ & $2.4-2.6$ & $1.7-2.4$ \\
Unit Emergy Value, excl. labor & $10^{5} \mathrm{sej} / \mathrm{J}$ & 2.2 & $1.8-1.9$ & $1.6-1.9$ & $1.2-1.5$ \\
Global Ren. Fraction, incl. labor & $\%$ & $38-48$ & $41-46$ & $45-47$ & $49-66$ \\
Global Ren. Fraction, excl. labor & $\%$ & $48-55$ & $55-60$ & $66-70$ & $69-87$ \\
\hline
\end{tabular}

${ }^{\text {a }}$ Technology options are described in Sections 2.1 and 2.2.

Focusing on results with labor included, the overlap of ranges indicates that the differences of the results are too small to rank technology options with certainty. Only Agroforestry has indicators that are significantly better than PP when labor is included, based on the sensitivity analysis. In results 
excluding labor, there is a stronger trend that integrated approaches have lower UEVs and higher Global Renewability Fractions, specifically Agroforestry.

Adjusting only the Global Renewability Fraction of imported wood fuel explains about half of the Global Renewability Fraction range in PP when including labor and the entire range when excluding labor (not shown).

\section{Discussion}

The performance of the three integrated technology options compared to the present practice shows that it is possible to reduce simultaneously deforestation pressure, soil loss and synthetic fertilizer dependence. Agroforestry is the most effective technology in obtaining these reductions, followed by Village Biogas. An apparent trade-off is the increased reliance on direct labor inputs, particularly for Village Biogas. The Emergy Assessment indicates that the integrated approaches are at least as biophysically efficient and independent from non-renewable resources as present practice. This makes the integrated approaches strong candidates as substitutes for present practices in agricultural development during a transition of society toward independence from non-renewable resources. The implications of these findings are discussed below.

\subsection{Deforestation}

Deforestation entails severe consequences related to carbon loss, pollution, biodiversity and livelihood of peoples living in and near forests. Deforestation is caused by the interplay of several dynamics and it is difficult to isolate the effect of wood fuel usage [11]. We cannot determine whether the integrated approaches are sufficient to avoid deforestation, but large-scale implementation of practices that use farmland resources for cooking fuel, like the ones analyzed in this study, appears to be a significant contribution to stem the current deforestation trend. Kemausuor et al. [29] found that biogas production alone could replace more than a quarter of wood fuel use in Ghana, perhaps sufficient to stop net deforestation. Since maize and beans are grown extensively in Ghana, large-scale implementation of agroforestry practices with leucaena could also significantly reduce traditional wood fuel production practices and so lessen deforestation.

\subsection{Fossil-Fuel Independence}

Fossil-fuel derived agricultural inputs include synthetic nitrogen fertilizer, usually based on natural gas, pesticides, and fuels derived from oil. Fossil fuels are consumed also in the production of farm machinery and equipment. It has been argued that the sustainable development of farming systems should apply a step-wise approach by making incremental changes to existing technologies rather than attempting to implement radically new solutions that could lock systems onto a path that may prove unsustainable in the long-term [52]. The low-tech approaches studied in this paper focus on reducing synthetic fertilizer inputs. However, we stress that further adaptation to a fossil fuel-scarce future of the studied farming system is needed to substitute the functions provided by other fossil-based inputs, such as diesel and pesticides, with those based on renewable resources, such as sustainable biofuels and integrated pest management techniques.

\subsection{Soil Degradation}

Soil loss and soil degradation in Africa are caused primarily by vegetation cover removal, overgrazing and compaction from livestock, leaching and drastically reduced fallow periods [13]. The reduction in soil organic carbon (SOC) caused by such agricultural practices makes it difficult to maintain soil fertility, and in most parts of West African agro-ecosystems (except the forest zone), soils are inherently low in SOC [53]. Most of the nutrient balance studies from Africa show negative balances for nitrogen, potassium and phosphorus [14]. Soil degradation may be addressed through continued addition of external nutrients in the form of synthetic fertilizer. However, such a strategy may be unsustainable because of the stock-limited supply of critical plant nutrients (especially 
phosphorus) and may constitute a technological lock-in of agriculture with external inputs. The farming techniques involved in the integrated approaches analyzed above-e.g., the incorporation of organic matter and on-site nutrient recycling — can significantly reduce the dependence of the current system on external inputs without undermining soil fertility. Consequently, the carbon-building and nutrient-providing properties of tree species suitable for agroforestry, such as leucaena, may play a central role in maintaining productivity in maize-beans production systems in Ghana. The technologies in the integrated approaches do not depend strongly on livestock production but require only small quantities of manure to start up the biogas reactors. This places the technologies within reach of the many farmers in Ghana who do not rear significant amounts of livestock.

\subsection{Resource Use}

Emergy Assessment provides insight on the resource use associated with all significant inputs, and the dependence of inputs on renewable energy. When inputs are considered in a life-cycle perspective and adjusted for quality differences by conversion to the common metric of solar emjoules, it is possible to compare the technology options in an even setting. In the future, farming approaches that use resources more efficiently and that depend less on non-renewable energy resources have an advantage over currently used approaches. This suggests that biophysical efficiency and Global Renewability Fraction are relevant to include among indicators for the resilience of future farming systems.

In spite of the assumed improved storage and conversion efficiencies of the village-scale biogas technology compared to the household-scale biogas technology, the overall biophysical efficiency is not significantly increased. This indication of absence of economy of scale in a biophysical perspective opposes the typical perception of a positive economic effect of scale [23].

In the integrated technology approaches, external material inputs and their associated embodied labor are substituted by direct labor inputs. This apparent dematerialization may signify a localization effect since direct labor may be expected to be local. However, whether increased dependence on direct labor makes the integrated food and energy systems less vulnerable to external changes overall through increased dependence on local inputs is difficult to evaluate. Increased labor inputs will, all else held equal, contribute to lower biophysical efficiency (higher UEV), but employing more people in agriculture may be desirable for the empowerment of rural areas [54,55].

\subsection{Accounting for Labor}

The emergy assessment is carried out both with and without labor inputs. Including labor provides the full picture by accounting for the total resource requirements of production, acknowledging that any human-influenced activity relies on information from and organization by humans, and that the availability of these inputs are associated with resource use. In addition, inclusion of labor inputs demonstrates that there is a trade-off between material and energy inputs, on the one hand, and labor inputs on the other. Excluding labor focuses attention on material and energy inputs, enables use of the calculated UEVs for inputs in other assessment, and facilitates re-calculations that apply alternative labor accounting methods (see [49]).

Converting monetary cost to indirect labor counted in global man-hours is a development of the typical procedure that converts monetary cost directly to emergy. The applied approach maintains accounting of labor in physical units and facilitates the comparison of direct and indirect labor inputs.

Finally, our data (Table 2) indicates that biogas production increases labor requirements. The labor reductions in wood fuel provision are merely shifted to crop residue provision, biogas plant management and effluent return to fields. This challenges the argument of workload reduction often made in favor of biogas production as an alternative to wood fuel $[18,19]$. The labor data is associated with large uncertainty, and, therefore, the sensitivity analysis has included a range of $\pm 30 \%$ labor input. Among labor input uncertainties, the farmers selected may have an interest in underestimating their workload and we may have overestimated the labor requirement for recovering residues and operating the biogas plants. 
The hypothesis that biogas is a labor-saving substitute to wood fuel appears sensitive to feedstock/wood fuel type and distance to the feedstock/wood fuel source. The balance between labor reduction and labor increase is an issue that should be investigated further to ensure that an expectation of timesaving is not a false hope.

\section{Conclusions}

Are integrated food and bioenergy systems the way forward for transitioning small-scale agriculture in Ghana? Our analyses have demonstrated that the integrated approaches are functional alternatives to the present farming system in the study area and relevant in terms of key biophysical indicators. The crop residue-based biogas and maize/beans/leucaena agroforestry approaches depend less on non-renewable inputs (synthetic fertilizer), reduce soil degradation, and may contribute to limiting deforestation in surrounding areas. How these approaches compare to present practice in terms of social and economic indicators of sustainable development should be topics of further research.

Reductions in external energy and material input use are associated with increased labor inputs, but overall and with the applied assumptions, the integrated approaches are as efficient in providing food and cooking fuel. Furthermore, the integrated approaches are at least as "renewable" in the sense that fractions of renewable flows relative to the total input are the same or higher for these technologies compared to the present farming system. Agroforestry appears a more attractive option in terms of resource use efficiency and renewability than the biogas-based technologies. We have found no significant difference between household-scale and village-scale biogas production indicating the absence of a significant relationship between biophysical efficiency and biogas production scale. Furthermore, the inclusion of biogas technologies does not seem to result in workload reduction.

Faced with multiple constraints in the form of increased scarcity of key farming inputs, reduced availability of wood fuels and degrading soil, farmers in the developing world are forced to adapt. For farmers in a rural area, as the one we have studied in Ghana, integrated food and energy systems based on biogas or agroforestry are concrete and ready-to-implement solutions. These solutions simultaneously reduce external fertilizer inputs, reduce soil loss and lessen the pressure on deforestation.

Supplementary Materials: The following are available online at www.mdpi.com/2071-1050/8/5/404/s1.

Acknowledgments: We acknowledge Francis Kemausuor for providing primary data on recoverability fractions and wood fuel usage, Evans Yakah (Kwame Nkrumah University of Science and Technology, Ghana) for field work assistance, Sune Thomsen, Stefan Heiske and Jorge Londoño (Technical University of Denmark) for biogas expertise, Henrik Haugaard (Roskilde University Center, Denmark) for soil fertility expertise, and farmers from Zambrama for taking time to talk and teach. This research was financially supported by the Danish International Development Agency (DANIDA) through the project "Biofuel production from lignocellulosic materials-2GBIONRG", DFC journal No. 10-018RISØ.

Author Contributions: Andreas Kamp, Simon Bolwig and Hanne Østergård designed the collection of empirical data; Andreas Kamp collected and analyzed the data. All authors took part in writing the paper.

Conflicts of Interest: The authors declare no conflict of interest.

\section{Abbreviations}

The following abbreviations are used in this manuscript:

PP

$\mathrm{HH}$

sej

tdm

UEV

USD

Global Ren. Fraction
Present Practice

Household

solar emjoule

tonne dry matter

Unit Emergy Value

United States Dollar

Global Renewability Fraction 


\section{References}

1. Hirsch, R. The Inevitable Peaking of World Oil Production; Atlantic Council: Washington, DC, USA, 2005; Volume XVI, pp. 1-10.

2. Krausmann, F.; Gingrich, S.; Eisenmenger, N.; Erb, K.H.; Haberl, H.; Fischer-Kowalski, M. Growth in global materials use, GDP and population during the 20th century. Ecol. Econ. 2009, 68, 2696-2705. [CrossRef]

3. UNEP. Decoupling Natural Resource Use and Environmental imPacts from Economic Growth. A Report of the Working Group on Decoupling to the International Resource Panel. 2011. Available online: http:/ /www.unep.org/resourcepanel/decoupling/files/pdf/Decoupling_Report_English.pdf (accessed on 15 April 2016).

4. International Assessment of Agricultural Knowledge, Science and Technology for Development (IAASTD). Agriculture at a Crossroads. Synthesis Report. 2009. Available online: http://www.unep.org/ dewa/agassessment/reports/IAASTD/EN/Agriculture\%20at\%20a\%20Crossroads_Synthesis\%20Report\%2 0\%28English\%29.pdf (accessed on 15 April 2016).

5. UNEP. Assessing the Environmental Impacts of Consumption and Production. 2010. Available online: http:/ / www.greeningtheblue.org/sites/default/files/Assessing\%20the\%20environmental\%20impacts \%20of \%20consumption\%20and\%20production.pdf (accessed on 15 April 2016).

6. Neff, R.A.; Parker, C.L.; Kirshenmann, F.L.; Tinch, J.; Lawrence, R.S. Peak oil, food systems and public health. Am. J. Public Health 2011, 101, 1587-1597. [CrossRef] [PubMed]

7. Markussen, M.V. Sustainability Assessment of Food and Bioenergy Systems in a Societal Context-In a Time of Crisis. Ph.D. Thesis, Technical University of Denmark, DTU, Kongens Lyngby, Denmark, September 2013.

8. Østergård, H.; Finckh, M.R.; Fontaine, L.; Goldringer, I.; Hoad, S.P.; Kristensen, K.; Lammerts van Bueren, E.T.; Mascher, F.; Munk, L.; Wolfe, M.S. Time for a shift in crop production: Embracing complexity through diversity at all levels. J. Sci. Food Agric. 2009, 89, 1439-1445. [CrossRef]

9. Owusu, V.; Fosu, K.Y.; Burger, K. Intersectoral labor mobility and deforestation in Ghana. Environ. Dev. Econ. 2012, 17, 741-762. [CrossRef]

10. Ministry of Lands and Natural Resources. Ghana Investment Plan for the Forest Investment Program. 2012. Available online: http://www.fcghana.org/assets/file/Programmes/Forest_Investment_Plan_fip/ Ghana\%20\%20FIP\%20Final.pdf (accessed on 15 April 2016).

11. Boucher, D.; Elias, P.; Lininger, K.; May-Tobin, C.; Roquemore, S.; Saxon, E. The Root of the Problem. What's Driving Tropical Deforestation Today? 2011. Available online: http://www.ucsusa.org/sites/ default/files/legacy/assets/documents/global_warming/UCS_RootoftheProblem_DriversofDeforestation_ FullReport.pdf (accessed on 15 April 2016).

12. Agyeman, K.O.; Amponsah, O.; Braimah, I.; Lurumuah, S. Commercial charcoal production and sustainable community development of the Upper West Region, Ghana. J. Sustain. Dev. 2012, 5, 149-164. [CrossRef]

13. Botchie, G.; Seini, W.; Asuming-Brempong, S. FAO Roles of Agriculture (ROA) project. Socio-Economic Analysis and the Roles of Agriculture in Developing Countries. 2003. Available online: ftp:/ /ftp.fao.org/es/esa/roa/pdf/Brief3-e.pdf (accessed on 15 April 2016).

14. Cobo, J.G.; Dercon, G.; Cadisch, G. Nutrient balances in African land use systems across different spatial scales: A review of approaches, challenges and progress. Agric. Ecosyst. Environ. 2010, 136, 1-15. [CrossRef]

15. Ray, D.K.; Ramankutty, N.; Mueller, N.D.; West, P.C.; Foley, J.A.F. Recent patterns of crop yield growth and stagnation. Nat. Commun. 2012, 3, 1293. [CrossRef] [PubMed]

16. Pittelkow, C.M.; Liang, X.; Linquist, B.A.; van Groenigen, K.J.; Lee, J.; Lundy, M.E.; van Gestel, N.; Six, J.; Venterea, R.T.; van Kessel, C. Productivity limits and potentials of the principles of conservation agriculture. Nature 2014, 517, 365-367. [CrossRef] [PubMed]

17. Bond, T.; Templeton, M.R. History and future of domestic biogas plants in the developing world. Energy Sustain. Dev. 2011, 15, 347-354. [CrossRef]

18. Amigun, B.; Parawira, W.; Musango, J.K. Anaerobic biogas generation for rural area energy provision in Africa. In Biogas; Kumar, S., Ed.; InTech: Rijeka, Croatia, 2012; pp. 35-62.

19. Arthur, R.; Baidoo, M.F.; Antwi, E. Biogas as a potential renewable energy source: A Ghanaian case study. Renew. Energy 2011, 36, 1510-1516. [CrossRef]

20. Chanakya, H.N.; Bhogle, S.; Arun, R.S. Field experience with leaf litter-based biogas plants. Energy Sustain. Dev. 2005, 9, 49-62. [CrossRef] 
21. Altieri, M.A.; Nicholls, C.I. Agroecology scaling up for food sovereignty and resiliency. Sustain. Agric. Rev. 2012, 11, 1-29.

22. Akinnifesi, F.K.; Ajayi, O.C.; Sileshi, G.; Chirwa, P.W.; Chianu, J. Fertiliser trees for sustainable food security in the maize-based production systems of East and Southern Africa. Agron. Sustain. Dev. 2010, 30, 615-629. [CrossRef]

23. Svensson, L.M.; Christensson, K.; Björnsson, L. Biogas production from crop residues on a farm-scale level in Sweden: Scale, choice of substrate and utilisation rate most important parameters for financial feasibility. Bioprocess Biosyst. Eng. 2006, 29, 137-142. [CrossRef] [PubMed]

24. Bogdanski, A.; Ismail, M. NRC Integrated food energy systems (IFES). Environ. Nat. Resour. Manag. Work. Pap. 2012, 49, 1-10.

25. Odum, H.T. Environmental Accounting: Emergy and Environmental Decision Making; Wiley and Sons: New York, NY, USA, 1996.

26. Keita, J.D. Wood or charcoal—Which is better? Unasylva 1987, 39, 137-138.

27. Lefroy, E.; Rydberg, T. Emergy evaluation of three cropping systems in southwestern Australia. Ecol. Model. 2003, 161, 195-211. [CrossRef]

28. Cannon, K. Soil Organic Matter. Organic Carbon and Nitrogen. Available online: http://www1.agric. gov.ab.ca/\$department/deptdocs.nsf/all/aesa1861/\$file/organicmatter.pdf?OpenElement (accessed on 13 April 2016).

29. Kemausuor, F.; Kamp, A.; Thomsen, S.T.; Bensah, E.C.; Østergård, H. Assessment of biomass residue availability and bioenergy yields in Ghana. Resour. Conserv. Recycl. 2014, 86, 28-37. [CrossRef]

30. Thomsen, S.T.; Spliid, H.; Østergård, H. Statistical prediction of biomethane potentials based on the composition of lignocellulosic biomass. Bioresour. Technol. 2014, 154, 80-86. [CrossRef] [PubMed]

31. Emery, I.R.; Mosier, N.S. The impact of dry matter loss during herbaceous biomass storage on net greenhouse gas emissions from biofuels production. Biomass Bioenergy 2012, 39, 237-246. [CrossRef]

32. Heiske, S.; formerly Technical University of Denmark, Lyngby, Denmark; Londoño, J.; Technical University of Denmark. Personal communication, 2013.

33. Bhattacharya, S.C.; Abdul Salam, P. Low greenhouse gas biomass options for cooking in the developing countries. Biomass Bioenergy 2002, 22, 305-317. [CrossRef]

34. Thomsen, S.T.; formerly Technical University of Denmark; Heiske, S.; formerly Technical University of Denmark. Personal communication, 2013.

35. Chanakya, H.N.; Ganguli, N.K.; Anand, V.; Jagadish, K.S. Performance characteristics of a solid-phase biogas fermentor. Energy Sustain. Dev. 1995, 1, 43-46. [CrossRef]

36. Burri, M.; Martius, G. Conception and construction of a dry fermentation pilot plant for developing countries. In Biogas from Solid Waste; Swiss Federal Institute of Technology in Zürich (ETH): Zürich, Switzerland, 2011; Available online: https://www.eawag.ch/fileadmin/Domain1/Abteilungen/sandec/ publikationen/SWM/Anaerobic_Digestion/Burri_2011.pdf (accessed on 15 April 2016).

37. Kang, B.T.; Wilson, G.F.; Sipkens, L. Alley cropping maize (Zea mays L.) and leucaena (Leucaena leucocephala Lam) in southern Nigeria. Plant Soil 1981, 63, 165-179. [CrossRef]

38. Cook, B.G.; Pengelly, B.C.; Brown, S.D.; Donnelly, J.L.; Eagles, D.A.; Franco, M.A.; Hanson, J.; Mullen, B.F.; Partridge, I.J.; Peters, M.; et al. Tropical Forages: An Interactive Selection Tool. 2016. Available online: http://www.tropicalforages.info/key/Forages/Media/Html/Leucaena_leucocephala.htm (accessed on 15 April 2016).

39. Kang, B.T.; Grimme, H.; Lawson, T.L. Alleu cropping sequentially cropped maize and cowpea with Leucaena on a sandy soil in Southern Nigeria. Plant Soil 1985, 85, 267-277. [CrossRef]

40. Lal, R. Agroforestry systems and soil surface management of a tropical alfisol: I: Soil moisture and crop yields. Agrofor. Syst. 1989, 8, 7-29. [CrossRef]

41. Remington, T.; Eklou-Takpani, K. Alley farming in central Togo. In Alley Farming in the Humid and Subhumid Tropics, Proceedings of the International Workshop, Ibadan, Nigeria, 10-14 March 1986; International Development Research Centre: Ottawa, ON,Canada, 1989; pp. 137-138.

42. Ngambeki, D.S. Economic evaluation of alley cropping leucaena with Maize-Maize and Maize-Cowpea in Southern Nigeria. Agric. Syst. 1985, 17, 243-258. [CrossRef]

43. Brown, M.T., Sweeney, S., Campbell, D.E., Huang, S.-L., Rydberg, T., Ulgiati, S., Eds.; Emergy Synthesis 8: Theory and Applications of the Emergy Methodology; University of Florida: Gainesville, FL, USA, 2015. 
44. Odum, H.T.; Brown, M.T.; Brandt-Williams, S. Handbook of Emergy Evaluation Folio 1: Introduction and Global Budget; University of Florida: Gainesville, FL, USA, 2000.

45. Bastianoni, S.; Marchettini, N. The problem of co-production in environmental accounting by emergy analysis. Ecol. Model. 2000, 129, 187-193. [CrossRef]

46. Kamp, A.; Østergård, H. How to manage co-product inputs in emergy accounting exemplified by willow production for bioenergy. Ecol. Modell. 2013, 253, 70-78. [CrossRef]

47. Wright, C.; Østergård, H. Scales of renewability exemplified by a case study of three Danish pig production systems. Ecol. Modell. 2015, 315, 28-36. [CrossRef]

48. Cavalett, O.; de Queiroz, J.F.; Ortega, E. Emergy assessment of integrated production systems of grains, pig and fish in small farms in the South Brazil. Ecol. Modell. 2006, 193, 205-224. [CrossRef]

49. Kamp, A.; Morandi, F.; Østergård, H. Development of concepts for human labor accounting in Emergy Assessment and other Environmental Sustainability Assessment methods. Ecol. Indic. 2016, 60, 884-892. [CrossRef]

50. Brown, M.T.; Ulgiati, S. Understanding the global economic crisis: A biophysical perspective. Ecol. Modell. 2011, 223, 4-13. [CrossRef]

51. World Bank. Labor Force, Total Datasheet. Available online: http://data.worldbank.org/indicator/ SL.TLF.TOTL.IN (accessed on 15 April 2016).

52. Robèrt, K.H.; Broman, G.I.; Basile, G. Analyzing the concept of planetary boundaries from a strategic sustainability perspective: How does humanity avoid tipping the planet? Ecol. Soc. 2013, 18. [CrossRef]

53. Bationo, A.; Kihara, J.; Vanlauwe, B.; Waswa, B.; Kimetu, J. Soil organic carbon dynamics, functions and management in West African agro-ecosystems. Agric. Syst. 2007, 94, 13-25. [CrossRef]

54. Agostinho, F.; Ortega, E. Integrated food, energy and environmental services production as an alternative for small rural properties in Brazil. Energy 2012, 37, 103-114. [CrossRef]

55. Ikerd, J.E. The need for a system approach to sustainable agriculture. Agric. Ecosyst. Environ. 1993, 46, 147-160. [CrossRef]

(C) 2016 by the authors; licensee MDPI, Basel, Switzerland. This article is an open access article distributed under the terms and conditions of the Creative Commons Attribution (CC-BY) license (http://creativecommons.org/licenses/by/4.0/). 